\title{
The Educative Game as a Sensitization Strategy for the Collection of Data with Adolescents ${ }^{1}$
}

\author{
Tatiana Yonekura² \\ Cássia Baldini Soares ${ }^{3}$
}

The aim of this study was to understand and analyze the potential of a game as a sensitization strategy for the performance of focal groups with adolescents in investigations into values. Twenty nine groups were realized in 10 social institutions of the municipality of Santo André. The sample was composed of 209 adolescents of 15 to 19 years of age. The results indicated that the majority expressed themselves without difficulties, discussing each of the valorative expressions drawn during the game with resourcefulness, involvement and respect for differing opinions, as well as being a method to promote reflection and stimulate debate about social values. Conclusions: The game was adequate for the collection of data. The ludic character allowed the participation of adolescents in an intense, relaxed, enjoyable and interactive way, which facilitated the deepening of discussions on the topic. The evaluation also identified a strong motivation for adolescents to discuss social values. Descriptors: Games, Experimental; Adolescent; Focus Groups; Educational Technology; Data Collection; Nursing.

\footnotetext{
${ }^{1}$ Supported by FAPESP, process \# 06/51671-9

${ }^{2}$ RN, Master's Student, Escola de Enfermagem, Universidade de São Paulo, SP, Brazil. E-mail: tatiana.yonekura@usp.br.

${ }^{3}$ RN, Ph.D. in Education, Associate Professor, Escola de Enfermagem, Universidade de São Paulo, SP, Brazil. E-mail: cassiaso@usp.br.
} 


\section{O jogo educativo como estratégia de sensibilização para coleta de dados com adolescentes}

O objetivo deste estudo foi conhecer e analisar a potencialidade de um jogo como estratégia de sensibilização para a consecução de grupos focais com adolescentes, em investigações sobre valores. Foram realizados 29 grupos em 10 instituições sociais, do município de Santo André, SP A amostra foi composta por 209 adolescentes de 15 a 19 anos. Os resultados indicaram que a maioria se expressou sem dificuldades, discutindo cada uma das frases com desenvoltura, envolvimento e respeito às opiniões divergentes, além de ser um método capaz de promover a reflexão e estimular o debate acerca de valores sociais. Pode-se concluir que o jogo mostrou-se adequado para a apreensão de dados. O caráter lúdico possibilitou a participação dos adolescentes de forma intensa, descontraída, prazerosa e interativa, o que facilitou o aprofundamento das discussões sobre o tema. A avaliação também permitiu identificar forte motivação dos adolescentes para discutir valores sociais.

Descritores: Jogos Experimentais; Adolescente; Grupos Focais; Tecnologia Educacional; Coleta de Dados; Enfermagem.

\section{El juego educativo como estrategia de sensibilización para recolección de datos con adolescentes}

El objetivo de este estudio fue conocer y analizar el potencial de un juego como estrategia de sensibilización para la consecución de grupos focales con adolescentes en investigaciones sobre valores. Fueron realizados 29 grupos en 10 instituciones sociales del municipio de Santo André. La muestra fue compuesta por 209 adolescentes entre 15 y 19 años. Los resultados indicaron que la mayoría se expresó sin dificultades, discutiendo cada una de las frases con desenvoltura, envolvimiento y respeto a opiniones divergentes, además de ser un método capaz de promover la reflexión y estimular el debate acerca de valores sociales. Se concluye que el juego se mostró adecuado para la obtención de datos. El carácter lúdico posibilitó la participación de los adolescentes de una forma intensa, informal, placentera e interactiva, lo que facilitó el profundizar las discusiones sobre el tema. La evaluación también permitió identificar una fuerte motivación de los adolescentes para discutir valores sociales.

Descriptores: Juegos Experimentales; Adolescente; Grupos Focales; Tecnología Educacional; Recolección de Datos; Enfermería.

\section{Introduction}

The literature on the use of educational games in the area of health discusses their applicability in various situations, which involve children, adolescents and adults. In general, it can be said that internationally the use of this pedagogic resource excels in the teaching of professionals in the area of health ${ }^{(1)}$ and particularly of nursing(2). In Brazil, educational games are used as a health education strategy ${ }^{(3-7)}$. No studies were found, however, that evaluate the use of games in a situation of data collection with adolescents.
The game is considered by its proponents, in the area of health, an educational instrument potentially capable of contributing much to the development of education as well as to the construction of health knowledge. Regarding the participants, the game is seen as a fun, stimulating, interactive, innovative and illustrative activity, which responds to the dual task of clarifying questions and facilitate learning ${ }^{(3-4)}$.

Thus the games are perceived as activities that enhance the creativity of those involved and provide a 
pleasant environment for learning, necessary to bring to the surface the potential to facilitate the dynamism of the context of learning and the construction of knowledge from the reality ${ }^{(4)}$.

Ludic activities, besides being a source of pleasure and discovery for the participants, also constitute a way of translating the socio-historical context reflected in the culture, which contributes significantly to the process of critical construction of knowledge of the participants. To learn to play enriches views of the world and stimulates relationships with peers, constituting a process of exchange of experience and of socialization(8).

In the area of health, the games are considered features that facilitate the discussion of relevant topics, such as diabetes ${ }^{(6)}$, infant respiratory infections ${ }^{(9)}$, postpartum care(5), and even sensitive issues such as drugs $^{(7)}$ and $\operatorname{AIDS}^{(3-4)}$.

Although the use of games in health education is not new, it represents an innovative pedagogic perspective in the part that criticizes the more authoritarian and rigid traditional pedagogic models. This is a perspective that makes reference to the multidimensionality of the healthsickness process, with the aim that the participants in the educational process are able to exercise criticism of the reality of health and seek collective mechanisms to transform it(7).

Educational games, ludic and interactive, are instruments that valorize the experiences and knowledge of the participants and encourage individual expression, in a group situation, restoring dialogue between educators and participants ${ }^{(7)}$.

The development of innovative educational technologies, focused on health education, cannot dispense with the process of evaluation, which is able to provide subsidies for prevention programs ${ }^{(7)}$. In general, it can be said that the literature portrays the educational games as health education process instruments that promote participation and the collective construction of knowledge, through discussions and exchange of experiences in a critical perspective in relation to traditional education. These propositions are consistent with the theoretical-methodological perspective of Public Health that supports this research. This field of knowledge and practices reiterates the historical and social character of the health-disease process and proposes that the health education process has an emancipatory character, thus constituting itself in a movement to comprehend the reality of health and health care ${ }^{(10)}$.

The emancipatory educational perspective, as formulated from the field of Public Health, is based in a critical theoretical and methodological framework ${ }^{(10)}$. In the philosophical dimension, formulators seek sources in the concept of praxis - the application of theory in man's practical action of transformation of nature. This transformation materializes through the conscious actions of man, which have the property of making its practice intentional and are performed through the praxis of labor and other social practices(11). It is also part of the concept of education as the appropriation of historically accumulated knowledge, capable of transmitting culture from one generation to another, which focuses on the transformation of different social praxis: the students are considered subjects and producers of their own education, capable of intervening in the social and health reality ${ }^{(12)}$.

The historical-critical pedagogy, grounded in the dialectical perspective, also consists of a theoreticalmethodological framework, which seeks to encourage dialogue between students and educators, valorizing the historically accumulated cultural dimension and the social determinants of education, in pursuit of social transformation and an egalitarian society. In this pedagogy, although the method is essential to the pedagogic process, it does not guarantee, by itself, a qualitative change in the understanding of social practice. In this direction, the importance of an active position of the social agents responsible for the mediation of pedagogical action is reiterated, since they are transforming elements of social practice(13).

This study is based on the assumption that educational games are methodological instruments capable of generating reflections, critical discussion of complex issues, and construction of collective opinions, from the reality of those involved and, ultimately, is able to generate new social practices.

The aim of this study was to identify and analyze the potential of an educational game as a strategy for data collection with adolescents.

\section{Methodological procedures}

This descriptive study, with a qualitative and quantitative approach, is a subproject of a larger project entitled 'Youth, values and drug consumption: public policies from the perspective of Collective Health', which sought to expose the values of adolescents from different social groups in the municipality of Santo André (RMSP). It was approved by the Research Ethics Committee of the School of Nursing of the University of São Paulo and by the Research Ethics Committee of the Health Department of Santo André. 
The study employed an adaptation of an educational game used in research into youth values ${ }^{(14)}$. With the intention of sensitizing adolescents for the discussion and exploration of the values of the group, the authors use a continuous scheme of assigning values to certain situations proposed by the researcher ${ }^{(14)}$.

This study takes value as a fundamental element to guide choices, desires, aspirations and actions. In class structured societies, the values accumulated by the culture are heterogeneous, since they are qualities attributed to things and situations by human beings in society and are not natural or universal, they depend on the position that each class occupies in the dynamics of social life(15).

Thus, to be part of the data collection, high schools were selected, according to a predefined proportionality to cover unequal areas of the regions of the municipality classified in another study as Central, Almost central, Peripheral and Almost peripheral, so that the more the adolescents and their families had access to wealth and citizenship, the more they are centrally located in the city. The groups were conducted in 10 selected schools which agreed to participate.

After explaining the study to employees of the schools (principals, pedagogical coordinators, teachers, etc.), adolescents and parents were invited to participate in the research. Adolescents who agreed to participate in the research and were over 18 years of age and those responsible for the students under 18 years of age, signed the free prior informed consent form.

The game is performed in accordance with the strategies for conducting focus groups, a qualitative research technique that uses group discussions to obtain data on specific issues of interest to the researcher, enabling participants to express, in their own terms, experiences, points of views, beliefs, values, attitudes and representations ${ }^{(16)}$. The focus group is led by a moderator, who takes a position of facilitator of the discussion process and seeks to encourage the debate and to limit their interventions, acting mainly in the introduction of new issues and the direction of the discussion. In addition, the moderators work is aided by an observer, which in this case, followed and noted the behavior of group members in a spreadsheet ${ }^{(17)}$.

The game uses the following materials: cardboard with a drawing of a continuous line that goes from the position completely agree to the position completely disagree (Figure 1), phrases that express values written on small pieces of paper, a bag to put the folded papers with the phrases, colorful stickers, pens and ID badges.

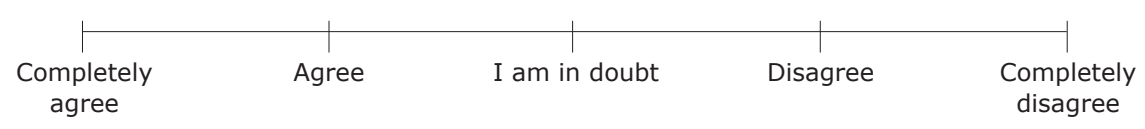

Figure 1 - Schematic of the game used for the apprehension of juvenile values

The chairs are positioned in a circle and the cardboard placed in the center of the room, preferably on a table. In this work, after presenting the moderator, the ID badges and colorful stickers were given to all participants of the circle who wrote their names, to facilitate identification and group interaction.

A set of expressions originally used in the game was pre-selected and translated by the researchers, according to the theoretical frameworks that guided the research. In this process, the expressions selected were grouped according to their relationship with: success; safety, confidence and the future; drugs and other forms of welfare and pleasure.

To promote better adaptation to the Brazilian reality, the expressions were passed for the judgment of three youth groups from different regions of Greater São Paulo, who tuned the language, removed some of the initially selected expressions and added others. The final list was composed of 73 expressions.
Each participant had the opportunity to draw an expression. After reading the phrase drawn, each one placed their sticker on a point on the continuous line. It was necessary to clarify that each participant could put their adhesive on top of others if they shared the same opinion. In a second step, the participants explained their choices, proceeding as a discussion on the topic. All participants were advised of the possibility to change their minds during the discussion and several did so.

Before beginning the activities themselves, the operating rules of the group were discussed: to respect the right of everyone to say what they think; to encourage dissenting opinions and not repress them; not to speak when others are speaking, seeking to express themselves at their time; to avoid parallel discussions so that everyone can contribute; to maintain confidentiality of data; to try not to dominate the discussion; to understand that the group is opinionated and, therefore, that there is no right or wrong opinion. 
At the end of each meeting the youths reported the experience of participating in the group and were invited to complete an evaluation form, with the following questions: From 1 to 10 how would you rate the game? Did the game promote reflection? Where the subjects covered of interest to you? Have you changed your opinion about any issue? Did you feel comfortable during the game? Would you participate again in the same kind of game? What did you like most about the activity? What do you least enjoy about the activity? Suggestions. The observations and notes made by the researchers in the observer's spreadsheet were also considered.

The sample consisted of 209 adolescents, 15-19 years of age, attending high school, with $57.6 \%$ female and $42.4 \%$ male, in a total of 29 groups.

\section{Results and Discussion}

The number of participants per game ranged from 5 to 11 , averaging 7.1. The duration of each group ranged from 40 minutes to two hours and was mainly related to the number of participants. The adolescents assigned a mean grade of 9.5 to the game, while the lowest grade achieved was 7. Small groups with five or fewer participants were not well evaluated by the adolescents and neither were those with more than 10 participants per game.

The literature recommends that the focus group have 6 to 10 participants, but several studies have used between 4 and 12 participants, depending on issues related to the goal, objectives, time and funding. However it is known that fewer than 6 can complicate the support of discussion and greater than 10 may hinder the control of the group ${ }^{(16-17)}$, as occurred in this study.

There was a significant acceptance of the game by the adolescents, which stimulated debate about social values. Most expressed themselves without any difficulties, discussing each of the sentences with ease and demonstrating involvement and respect for differing opinions. Regarding the reflection of the topics covered, $99.5 \%$ of the adolescents revealed that this method is able to promote reflection and $64.1 \%$ claimed to have changed their opinion about some issue after the activity. The adolescents said that the relaxed atmosphere and the freedom to express opinions facilitated the reflection on the issues addressed and the respect for the opinion of the colleague.

The promotion of dialogue and debate of current issues through games can facilitate the approach and the inclusion of these topics into social institutions and the family, since there are certain difficulties in dealing with such matters, considered important for the formation of the individuals ${ }^{(7)}$.

A study that aimed to evaluate an educational game about drugs found that teens appreciate the interactive approach of the games, since it favors dialogue, encourages the sharing of problems and solutions and active participation in the activity(7).

Among the advantages of the focus group, the literature correctly insists that the group activity permits a critical discussion and centralizing of the group on a subject, and an increased possibility of constructing opinions and reflection in the interaction with other people. The reflection of the participants about quotidian problems contributes to finding solutions together ${ }^{(16)}$. Furthermore, it is stressed that the reflection process ultimately results in overcoming prejudices and culturally entrenched myths, with positioning changes in the process ${ }^{(10,17)}$.

Most adolescents (99.5\%) stated that the topics discussed were of interest to them, $96.8 \%$ responded that they felt comfortable during the game, $96.6 \%$ would like to participate in the game again. It was possible to relate the fact that a few adolescents referred to not wanting to participate again due to the large number of participants in their groups and the prolonged duration, which was also reflected in the score given to the game.

The positive results of this study are consistent with other advantages arising from the literature, which also emphasizes the power of games to develop discussions on delicate and personal issues, which contain strong subjective components. The ludic, uninhibited character, encourages participants to propose, to justify and defend something they believe, as well as enables the exchange of experiences based on the thematic content of the subject being worked with, attempting to be close to the lived reality of participants ${ }^{(4)}$.

With regard to limitations and negative aspects, some participants considered that debate is discouraged when there is domination by members of the group, besides the occurrence of side conversations, which happened in large groups. The moderator has a set of tasks aimed at the proper flow of the debate. The importance of the rules must be emphasized at the beginning of the group and monitored throughout the discussions $^{(16)}$.

Another limitation is related to the lack of suitable rooms for the realization of the groups, as some occurred in environments with external noise, at recreation time, 
and/or were interrupted several times, sometimes by teachers wanting to use the rooms, sometimes by other adolescents curious about the activity.

It is known that the dynamic should be conducted in a quiet, comfortable, accessible and uncrowded place, ensuring privacy and silence for the recording of the tapes and listening among participants ${ }^{(16)}$. The environment affects the quality of the results and the moderator should be aware of factors that obstruct open discussion and free expression of the participants so that the different perceptions and viewpoints do not fail to be expressed(17).

The discussion with the adolescents also allowed it to be noted that there is not a monitored discussion in schools about youth values and allowed the claim by adolescents to continuously have more debates, in the school environment. In addition, they requested the inclusion of discussions on school issues and other more controversial issues such as ethics, human rights, citizenship, politics and global warming.

The data by social group showed that the adolescents of the groups Almost Periphery and Periphery evaluated the game better, since most attributed the score of 10 (80\% and $65.8 \%$, respectively), compared with adolescents of the other groups of Central and Almost Central ( $41.2 \%$ and $48 \%$ respectively). The lowest grade achieved in all groups was 7.

Regarding the change of opinion, there were differences between social groups. Most adolescents in the Central group (82.3\%) said they had a change of position after participating in the game, which differs from adolescents from the Peripheral group, in which only $56.1 \%$ reported a change of opinion. In the groups Almost central and Almost peripheral, the majority of adolescents also reported a change in opinion ( $80 \%$ and $68.5 \%$ respectively).

By incorporating the reality of those involved, the group discussions enable the critical analysis of the situation in which the participants find themselves, as it allows the complexity of knowledge, the overcoming of naive conceptions and practices and the development of a new consciousness ${ }^{(10)}$.

\section{Conclusion}

The game was extremely welcome among the adolescents, who emphasized the importance of the discussions. It is possible to state that this strategy is useful for data collection with adolescents, providing a moment of interaction, socialization and concentration to perform a critical discussion and from it construct opinions collectively.

The game was shown to be adequate for the collection of data, as a research tool, since it reached the proposed objectives with satisfactory results in a practical and relatively rapid way. Furthermore, the results indicate the pertinence of the use of games in the investigation of complex issues and in identifying the variability that may arise between groups located in different social contexts. However, as a research tool, the adoption of data collection in a group must be carefully chosen since there are also disadvantages and limitations.

The ludic character allowed the participation of adolescents, in an intense, relaxed, enjoyable and interactive way, which facilitated the deepening of discussions and allowed changes of opinion, resulting from the movement of deeper reflection on the theme. Through group discussions, the adolescents had the opportunity and interest to show their attitudes, beliefs and values, and to obtain new and different perceptions, stimulating new ideas. Thus it is recommended that the game is used when one wants to apprehend empirical data involving subjective aspects of the participants related to ideas, opinions, beliefs, prejudices, myths, among others. In the same direction, it is recommended to be used for collecting data from the adolescent, due to the dynamism that was particularly appreciated by participants.

It can be concluded that small groups with five or fewer members are not well assessed by the adolescents and may not achieve the proposed objectives and expectations of a group activity. Likewise, the participation of more than 10 members per game should be avoided since managing becomes more difficult and factors such as time, fatigue and other activities interfere with the final result.

The evaluation showed that this strategy has the power to encourage discussion of social values, as indicated by adolescents of different institutions, important in the formation, but almost always absent from the school. The strong motivation of the adolescents to discuss social values contributes to the formulation of proposals for education in the area. It also indicates the relevance of the game as an educational instrument to form a closer relationship between educators and adolescents, capable of providing a forum for discussion and exploration of issues that seem to be missing in the formation of most of these young people, especially those who find themselves in social contexts marked by 
negativity. Thus, it is recommended that the game is also used in educational group activities with youths, who emotionally receive the democratic debates that deal with current issues concerning the problems they are experiencing in the social reality.

The use of group work has recognized importance in several situations in the nursing area, both as a resource in the health care context as well as in the production of knowledge(18). It is hoped that with further evidence of the good applicability and potential of the games, the use of this instrument will constitute part of the practice of nurses and researchers as a dialogical and critical strategy able to consolidate the educational activities in an emancipatory perspective.

\section{References}

1. Blakely G, Skirton H, Cooper S, Allum P, Nelmes P. Educational gaming in the health sciences: systematic review. J Adv Nurs 2009; 65(2):259-69.

2. Royse MA, Newton SE. How gaming is used as an innovative strategy for nursing education. Nurs Educ Perspect 2007 September-October; 28(5):263-7.

3. Stefanelli MC, Cadete MMM, Aranha MI. Proposta de ação educativa na prevenção da AIDS: jogo educativo. Texto Contexto Enferm 1998 setembro-dezembro; 7(3):158-73.

4. Shall VT, Monteiro S, Rebello S, Torres M. Evaluation of the ZIG-ZAIDS game: an entertaining educational tool for HIV/Aids prevention. Cad Saúde Pública 1999; 15 (Supl 2):107-19.

5. Fonseca LMM, Scochi CGS, Mello DF. Educação em saúde de puérperas em alojamento conjunto neonatal: aquisição de conhecimento mediado pelo uso de jogo educativo. Rev. LatinoAm. Enfermagem. 2002 março-abril; 10(2):166-71.

6. Torres HC, Hortale VA, Schall VA. A experiência de jogos em grupos operativos na educação em saúde para diabéticos. Cad Saúde Pública 2003 julho-agosto; 19(4):1039-47.

7. Monteiro SS, Vargas EP, Rebello SM. Educação, prevenção e drogas: resultados e desdobramentos da avaliação de um jogo educativo. Edu Soc 2003 agosto; 24(83):659-78.

8. Melo CMR. As atividades lúdicas são fundamentais para subsidiar ao processo de construção do conhecimento. Inf Filos. 2005; 2(1):128-37.

9. Andrade RD, Mello DF, Scochi CGS, Fonseca LMM. Jogo educativo: capacitação de agentes comunitários de saúde sobre doenças respiratórias infantis. Acta Paul Enferm 2008; 21(3):444-8.
10. Soares CB, Campos CMS, Leite AS, Souza CLL. Juventude e consumo de drogas: oficinas de instrumentalização de trabalhadores de instituições sociais, na perspectiva da saúde coletiva. Interface Comun Saúde Educ 2009 janeiro-março; 13(28):189-99.

11. Vázquez AS. Filosofia da práxis. Rio de Janeiro (RJ): Paz e Terra; 1977.

12. Paro VH. Escritos sobre educação. São Paulo (SP): Xamã; 2001.

13. Saviani D. Escola e democracia: teorias da educação, curvatura da vara, onze teses sobre a educação política. 36.ed. Campinas (SP): Autores Associados; 2003.

14. Thomson R, Holland J. Youth values in transition to adulthood: an empirical investigation. London (UK): London South Bank University; 2004.

15. Viana N. Os valores na sociedade moderna. Brasília (DF): Thesaurus; 2007.

16. Morgan DL. Focus group as qualitative research. Newbury Park (CA): Sage Publication; 1997.

17. Cotrim BC. Potencialidades da técnica qualitativa grupo focal em investigações sobre abuso de substâncias. Rev Saúde Pública 1996 junho; 30(3):285-93.

18. Godoy MTH, Munari DB. Análise da produção científica sobre a utilização de atividades grupais no trabalho do enfermeiro no Brasil: 1980 a 2003. Rev. Latino-Am. Enfermagem. 2006 setembro-outubro; 14(5):786-802.

Received: May $22^{\text {th }} 2009$

Accepted: Oct. $6^{\text {th }} 2010$ 